2019 (112): 123-143.

(C) A szerző(k) 2019

replika.hu/replika/112

\title{
Böröcz József
}

\section{Histársadalom - kıskapuko}

„Et in Arcadia ego."

\begin{abstract}
Absztrakt: Ez az először mind angolul, mind magyarul húsz éve megjelent tanulmány a globális történeti-összehasonlító szociológia eszközeivel irányítja a figyelmet a magyar társadalom egyik szembeötlő jellegzetességére, a szinte mindent átfogó informalitásra. Azt firtatja, milyen társadalomtörténeti okokra vezethető vissza e sajátosság. Itt elsősorban a gazdaság területén megfigyelhető informalitás kapott hangsúlyt, bár tanulságos volna a politika, a kultúra, az elitek és a tömegek belső viszonyaiban testet öltő informalitás különféle kifejeződési formáit is szemügyre venni.
\end{abstract}

Kulcsszavak: informalitás-formalitás, magyar társadalom, kirekesztés, Polányi Károly, reciprocitás, társadalmiság, társadalomátalakulás, társadalomnagyság

Szerzője ezt az eredetileg angolul, az East European Politics and Societies címủ folyóirat számára készült, s annak tavaszi számában megjelenö tanulmányával rokon szöveget szánta válaszféléül Zentai Violettának a 20001999. szeptemberi számában megjelent írására. A Replikában ezt a fordítást közöljök újra a 2000 folyóirat jóváhagyásával.

1 Csokonai Vitéz Mihály sírfelirata. 
Irányítsuk képzeletbeli látcsövünket Arcadiára, erre az alig tízmilliós országra Latin-Amerika kellős közepén. ${ }^{2}$ Arcadiában mindent annyira behálóz az üzleti és közélet, a kultúra és az államszervezet informalitása, hogy az ország fővárosában, Malos Airesben ${ }^{3}$ élő külföldiek látogatta társaságokban jószerével másról sem esik szó, mint kenőpénzről, korrupcióról, maffiákról, összefonódásokról és patrónus-kliensi rendszerről. A köztereket ellepik az áruk és szolgáltatások legszélesebb skáláját kínáló, tolakodó utcai árusok és a higiéniai és adóelőírásokat csakúgy, mint a járókelők méltóságát semmibe vevő, silány árucikkek és még riasztóbb szolgáltatások tömegét kínáló, szánalmas bazárok. Az egyre előkelősödő Malos Aires-i kertvárosok felé tartó utak találkozásánál, a Plaza de la Ciudad Washingtonon hajnalonta borostás arccal, kialvatlanul álldogálnak a szomszédos, Arcadiánál szegényebb országokból hivatalos papírok nélkül érkezett munkavállalók, alkalmi munkalehetőségekre várva.

Arcadia politikai életét át- meg átszövi az informalitás. Miután a demokráciát jó két generációnyi időre felfüggesztő ezredesek uralmát eltakarította ugyanaz a geopolitikai logika, amely eredetileg odaültette őket, az arcadiai nyilvánosság gyorsan napirendre tért afölött, hogy a diktatúra utáni első választások során megválasztott kormány egy eladdig a nagypolitikában ismeretlen diplomáciatörténészt nevezett ki a külügyminiszteri posztra, mondván: érthető, hiszen az új külügyér az új miniszterelnök veje. A négy évvel későbbi választások során olyan politikai csoportok és politikusok kerültek hatalomra, amelyek-akik, úgy tünt, mintha köszönő viszonyban sem lettek volna az előző turnus kulcsszereplőivel. Ez az ország méretének és a hatalmi elitek működésmódjának ismeretében komoly teljesítmény, hiszen szinte valamennyi, az egymást követő kormányzati ciklusokban érintett politikus és szakértő a Malos Aires-i egyetem oktatói karából, illetve az ugyancsak a fóvárosban székelö, francia mintára a múlt században létrehozott Arcadiai Tudományos Akadémia társadalomkutatói közül került ki, s többségük egész életében Malos Aires három „jobb” kerületének lakója volt. A különféle ideológiai táborok képviselői és a politikai pártok kulcsemberei közötti kapcsolattartás hiánya, s a politikai beszédben valamennyi csoportozat által erősen hangsúlyozott, állítólagos habituális másságuk tehát igazán figyelemre méltó teljesítménynek számított. Ezt látva az ország legvitriolosabb tollú jegyzetírója „törzsi szervezetként” aposztrofálta az ország politikai rendszerét.

Az informalitás logikája annyira áthatja a közéletet, hogy az 1998-ban rendezett választásokat a „polgári rend” jelszavával nyerte meg a mindkét korábbi pártcsoport tagjaitól generációs alapon elkülönült új erő, a FINES-Partido Civico de Arcadia (FINES-PACA). A „polgári rend” jelentésének lényege adott közegben az (addigra már nyolc éve demokratikus) kormányzat legmagasabb szintjeit és az üzleti élet elitjét összekötő informalitás elleni küzdelem ígérete volt: a FINES-PACA miniszterelnök-jelöltjének egyik legnépszerübb választási ígérete abban állt, „mindenki eldobhatja a telefonnoteszét.” Ám alig alakult meg az új kormány, nyomban kiderült, hogy az új „polgári rend” fogalma két fö elemet foglal magában: (1) az előző kormányzat és annak (vélt vagy valós) kliensei elleni fellépést a kormányzati hatalom minden eszközével, illetve (2) egy, a közvéleménynek szóló kampányt úgymond a „külföldibűnözés” és „a maffiák” ellen. Mára, két évvel a FINES-PACA és rurális-geriátriai

2 A térséget, melyben Arcadia elhelyezkedik, a különféle környező nagyhatalmak viszályainak és stratégiai játszmáinak történetével összefüggő okoknál fogva hol „Dél-”, hol „Közép-”, hol „Dél-Közép”-Latin-Amerikának nevezik.

3 Malos Aires nevét az északi látogatók gyakran összekeverik Maláriával, Arcadia szegényebb déli szomszédja, Aroma fővárosával; az ezzel kapcsolatos sértődés az arkád kultúra egyik jellegzetes toposza. 
bázisú, populista koalíciós partnere, a Partido Independiente de los Minimos-Padrones (PIMP) hatalomra kerülése után nyilvánvaló: az új kormány politikája nem az informális összefonódások, a patrónus-kliensi rendszer megszüntetésére, hanem e rendszer kulcspozícióinak megszerzésére irányul. Erre utal, hogy az új kormány által poszthoz és megélhetéshez juttatott minisztériumi tisztviselők, parlamenti képviselők és szakértők körében erősen túlreprezentáltak a Malos Aires-i egyetem három-négy diákotthonának volt lakói, s ezt jelzi az is, hogy az új miniszterelnök mind az Adóhivatal, mind pedig az Arcadiai Állam Vagyonát Kezelö Ügynökség élére kamaszkori barátait nevezte ki. E tény ismerete nélkül megmagyarázhatatlan volna, miért éppen e két, kinevezésükkor közteherviselési kötelezettség elmulasztása és közokirat-hamisítás vádjával vizsgálat alatt álló üzletember került ennek, az ország Amerikai Uniós felvétele előtt nemzetközi vonatkozásban is fontos két hivatalnak az élére. A kormány egyik tanácsadója, egy korábban Nyugat-Európában élő ügyvéd csak részben tréfálkozott, amikor kinevezését azzal magyarázta, hogy a miniszterelnök tíz évvel korábban, doktorandusz korában néhány hónapig nála lakott.

Ennyi talán elég is a képzeletbeli Arcadiáról. Fordítsunk egyet a távcsövön, s élesítsünk Magyarországra.

Az Angelusz Róbert és Tardos Róbert vezetésével, az államszocializmus összeomlása előtt három évvel készített, kiváló kérdőíves felmérés adatainak (lásd TÁRKI 1988a, 1988b, és 1988c $)^{4}$ újraelemzése során doktoranduszaimmal és kollégáimmal több összefüggésben is arra a következtetésre jutottunk, ${ }^{5}$ hogy az informális hálózatok nagysága és típusai - még a kvantitatív elemzés sok szempontból durva és pontatlan eszközei segítségével is jól kitapintható módon - növelték a társadalmi egyenlőtlenségeket, mérjük az utóbbiakat akár jövedelemben, akár lakásviszonyokban. Egy nemzetközi vizsgálat magyar válaszadói még a legrutinosabb adatelemzőket is meglepték, amikor 1996-ban a sikeres vállalkozáshoz szükséges dolgok listájából elsöprő többségben az informális kapcsolatokat választották, melyek így jócskán megelőzték még a tőkét is (lásd Örkény 1997: 239). A volt államszocialista vállalati vezetők informális társadalmi hálózatai oly lényeges elemeivé váltak az átalakulásnak, hogy nemcsak azt határozták meg, kik kerülnek az immár kapitalizmuskonformmá alakított vállalatok élére, és nem is csak azt, kinek a kezébe-nevére kerül az állami tulajdon, de jócskán befolyásolták a létrejövő új, tőkés vállalati szervezet szerkezetét is (Böröcz 1993). ${ }^{6}$ Mivel a vállalatszervezet az intézményi közgazdaságtannak és a gazdaságszociológia vele határos részének egyik fö empirikus vizsgálódási területe, ${ }^{7}$ ez utóbbi állítás elméleti implikációi meglehetősen messze vezetnek. Későbbi elemzések ${ }^{8}$ mind közvetlen megfigyelések alapján, mind pedig indirekt következtetésekkel alátámasztották e megfigyeléseket.

4 Feldolgozását lásd például Angelusz és Tardos (1991).

5 Közvetlenül Böröcz és Southworth (1995), illetve Bodnár és Böröcz (1996) támasztja ezt alá. Közvetve releváns még Böröcz és Southworth (1996) is.

6 De lásd közvetlen előzményként Böröcz (1990).

7 Lásd a „tranzakciós költség” megközelítés Oliver Williamson által képviselt változatát (például Williamson 1981, 1994).

8 A gazdaságszociológiában lásd például Magyarország kapcsán: Stark (1996); Magyarország és a volt NDK vonatkozásában: Stark és Bruszt (1998); több poszt-államszocialista országról szólván: Böröcz és Róna-Tas (1995). A jogszociológia területén lásd Scheppele és Örkény (1996-1997). 
Az alábbiakban történeti-összehasonlító szemszögből, a világ egyéb, nem kelet-közép-európai társadalmaiban megfigyelhető informalitás közegében próbálom értelmezni a magyar társadalom e szembetűnő vonását, s elgondolkodom a jelenség lehetséges társadalomtörténeti okain. Itt föként az informalitás gazdasági megnyilvánulási formáira összpontosítok. Hasonló eszmefuttatás minden bizonnyal ugyancsak elmondható volna a politikai szféra müködésmódja vagy a társadalmi elitek szerveződési mechanizmusai kapcsán.

\section{Informalitás és társadalmiság}

A szociológiában a „formális szervezet” fogalmát olyan csoportokra alkalmazzák, melyeknek müködését explicit és kézzelfogható - általában szakemberek által megfogalmazott, rituálisan elfogadott és többé-kevésbé minden érintett számára nyilvánosan hozzáférhető szabályok és elöírások fogják keretbe. A szabálykövető viselkedést formális magatartásnak nevezik; a társadalmi magatartások minden egyéb formája informális viselkedés. ${ }^{9}$

Az informalitásról, pontosabban a formalitás-informalitás viszony társadalomspecifikus normáiról igen nehéz moralizálás nélkül, történeti-összehasonlító összefüggésben szólni. Ennek az a fö oka, hogy az formalitás-informalitás viszonynak még a társadalomtudományos beszédmódját is átpolitizálja a „Nyugat” köznyelvből beszűrődő identitásdiszkurzusa. Mint azt a társadalomtudományok klasszikusai megfigyelték és mind elemzéseikben, mind pedig elméleteik előfeltevés-rendszerében megjelenítik, a „nyugati” ipari kapitalizmus történetének fontos fejezeteit áthatotta a formalitás morális elörébbvalóságának képzete. Párhuzamosan azzal, ahogy kialakult a modern kapitalizmus két, ma ismert legnagyobb intézménytípusa - az iparvállalati szervezet és a modern „nemzetállami” apparátus -, a „nyugati” társadalmak gyakorlata úgy változott meg, hogy tagjaik normarendszerébe beépült a társadalmi viselkedés területén a formális szabályok követésére vonatkozó elvárások egy meghatározott szintje és formája. Történeti-összehasonlító szemszögből azonban e sok szempontból fontos fejlemény történeti kivétel volt, méghozzá kettős értelemben. Egyrészt a formális szabálykövetés e moralizáló elvárása a világ Nyugat-Európán és ennek észak-amerikai kiterjesztésének egyes társadalmain kívüli, jó kilencven százalékában nem vált uralkodó toposszá. Pontosabban olyan morális rend alakult ki, melyben a formális magatartások és ezek informális alternatívái között könnyed, természetes, hanyag eleganciával mozognak a társadalom kompetens tagjai.

Másrészt kivétel ez a diszkurzív fejlemény abban az értelemben is, hogy a moralizáló, formalitáselvu” „nyugati” beszédmóddal még a nyugati társadalmi gyakorlatok legpuritánabb változatai sincsenek összhangban. Naivitás ugyanis azt képzelni, hogy a „nyugat” társadalmai betartják az összes érvényben levő formális szabályt és előírást, vagy hogy a formális

$9 \mathrm{Az}$ „informalitás” szikáran logikai szempontból tehát reziduális fogalom: határait a formalitás jelöli ki, negatív módon. E tekintetben logikai hiba a formalitás jelenléte nélkül informalitásról beszélni. Történeti és szociológiai értelemben ugyanakkor meröben más a helyzet. Mivel a formalitás közegében informalitásnak minősülő magatartások messze megelőzik a formális megjelenését mind társadalomtörténeti időben, mind pedig az egyénnél, az informalitást a társadalmi lét „természetes”, a formalitásnál „elörébb való” müködésmódjának tekinthetjük. Ha a szociológia valóban az a minden kulturális, történeti és földrajzi részrehajlástól mentes, történeti-összehasonlító tudományszak volna, amivé klasszikusai óta legjobbjai tenni szeretnék, nemcsak az informalitást, hanem a formális viszonyok kialakulását és fennmaradását is megpróbálná megragadni. 
szabályok ismerete önmagában értelmes és elégséges leírását adná e társadalmak müködésének. Épp ellenkezőleg: a társadalmi lét még a „nyugat” szabályozott társadalmaiban is elképzelhetetlen anélkül, hogy tagjainak kényelmesen, megbízhatóan és könnyüszerrel rendelkezésükre ne állna az informális magatartásformák gazdag választéka. Igen gazdag e választék, még akkor is, ha közép-európai szokás szerint amikor „világot” mondunk, annak csak a nyugat-európai és észak-amerikai szegletére gondolunk. Még az így definiált nyugaton belül is szédítő a formalitás-informalitás viszony formagazdagsága, gondoljunk arra, micsoda különbség lelhető fel a „korrupció” kulturálisan kódolt fogalmai között mondjuk svéd-olasz összehasonlításban. Mármost, még ha az összevetés alapját tovább szükítve a „nyugatnak” csak a protestáns-puritán szeletét hasonlítjuk a világ többi részéhez, akkor is aligha juthatunk arra a következtetésre, hogy az előbbi kizárólag vagy akár csak túlnyomórészt formális, az utóbbi pedig csak/jobbára informális volna, hiszen mindegyik formális is, informális is. A fö eltérés inkább az, hogy a protestáns-puritán „nyugat” reflexív alanya úgy tekinti, a testiséghez, a világi élvezetekhez, az intim, elengedett emberi kapcsolatok összes egyéb megnyilvánulásához hasonlóan az informalitás különféle megnyilvánulásai miatt is lelkifurdalást, bűntudatot kell éreznie. E felfogástól valóban távol áll a mai magyar gyakorlat.

$\mathrm{Az}$ informális elemeitől megfosztott társadalmi lét gondolata a legabszurdabb negatív utópiák közé tartozik. Mint azt a szociológia terepmunkásai a nagy ipari szervezetek és állami apparátusok kialakulásával egy időben igen helyesen megfigyelték, a mégoly formalizált, nagy szervezetek életének jelentős részét is szükségszerüen az informalitás ethosza szervezi. Úgy tűnik, bármely modern társadalmi-politikai rendszerben - így a kapitalizmus mégoly „fejlett” válfajaiban is - az emberek a társadalmi lét elengedhetetlen és fontos összetevőjeként tartják számon az informális viszonyok és eljárásmódok kínálta spontaneitást, közvetlenséget és kreativitást. A társadalmi lét legélvezetesebb, emberhez legméltóbb pillanatai mind-mind informális viszonyokban öltenek testet. Annak ismerete, hogy adott társadalom tagjai milyen helyzetekben, milyen informális szabályok mentén, milyen következményekkel kerülik meg a formális elöírásokat, s hogy milyen magatartási müfajokra terjed ki az általuk elfogadhatónak-élvezetesnek talált informális viszonyok köre, legalább annyit elárul a társadalom működéséről, mint a formális szabályok rendszere. Az igazán izgalmas terület a kettő viszonyában megfigyelhető változatosság megértése.

A formális szabályok léte szükségszerüen azzal jár, hogy az emberek így vagy úgy, de informális úton megkerülik, s egyéni igényeik, szükségleteik, lehetőségeik idioszinkretikus rendszeréhez idomítják őket. Az informalitás mindenütt jelen van: szervezetszociológiai értelemben tényleg minden nagykapu mellett van (legalább) egy kiskapu. Annak megértéséhez, hogy a nagy szervezetek formális szabályok betartatására hivatott középvezetői miért csak ritkán, vonakodva és akkor is rossz hatásfokkal sújtanak le az informális megoldásokra, két szempontot érdemes figyelembe venni. Egyrészt még a legformalizáltabb, legfegyelmezettebb társadalmakban is oly nagy a lehetséges informális megoldások száma, és skálájuk oly széles, hogy lehetetlen valamennyi informális megoldást kizárni. Emiatt az tűnik a legintelligensebb vezetői stratégiának, amely megelégszik az informalitás kordában tartásával, és arra törekszik, hogy lehetőség szerint csak a nagy szervezet müködésére nézve legártalmasabb formáit korlátozza az informalitásnak.

Ráadásul a kiskapuk bizonyos típusai nem szükségszerűen rontják a formális szervezetek működésének hatékonyságát - sőt. A különféle tulajdonosi és menedzseri rezsimekkel, döntésekkel, stratégiákkal és módszerekkel szembeni munkavállalói ellenállás egyik leg- 
szellemesebb módozata éppenséggel a sztrájk azon válfaja, amelyben a vállalat müködését nem munkabeszüntetéssel, hanem úgy lassítják vagy állítják le a dolgozók, hogy betűről betüre betartják a vállalat és ennek intézményi környezetét képezó állami és egyéb szervek és hatóságok összes szabályát, elöírását. A munkavállalói nyomásgyakorlás e módozatának léte önmagában jelzi, hogy a dolgozók - emberi lények lévén - apróbb-nagyobb informális megoldások ezrei segítségével teszik saját munkájukat könnyebbé (sok esetben: eleve lehetségessé), akár a formális szabályok ellenében is.

Ha bárki akkurátusan számba venné, valamely, mégoly formalizált „piaci” környezetben működő, mégoly formális belső rendszerű nagyvállalat mégoly sikeres vezetője pontosan mit is csinál napi munkája során, az elemzés aligha azzal nem végződne, hogy a cégirányítás mint tevékenység formális terminusokban aligha leírható. A vezetői munka óriási hányada nem más, mint „befektetés” a formális szabályrendszerekben nem rögzíthető, pontosan alig körvonalazható, informális hálózatok építésébe. A business school típusú vezetőképző intézmények tananyagának jelentős része az úgynevezett „személyközi kapcsolatokkal” összefüggő készségek fejlesztésére irányul. E kapcsolatok körébe magától értetődő módon tartozik bele nemcsak a beosztottakhoz, hanem a „piac” és az egyéb makrotársadalmi struktúrák logikája szerint egyenrangú partnerekhez és versenytársakhoz, illetve a felettesekhez füződő viszony is.

A kapitalizmus jó négy évszázados történetében a különféle, különböző mértékben zártkörü és elittermelő felsőoktatási intézményektől, kluboktól és egyetemi diákszervezetektől az exkluzív sporttevékenységeken és klubokon keresztül a jótékonysági bálokig és koncertekig kulturális mintáktól, nemzeti hagyományoktól és történeti közegtől függően intézmények egész sora szolgált kiszámítható, kulturálisan elfogadott terepként a tulajdonosi és menedzseri elitek tagjai közötti kapcsolatépítéshez. Az informalitás civiltársadalom-stimuláló szerepét jól mutatja, hogy a nyilvános intézmények - éttermek, kávéházak, kocsmák, szalonok, olvasókörök, vitafórumok, színházak, koncerttermek, mozik, terek, utcák, lakóházak stb. - informális társadalmi "profilja” hajszálpontos térkép formájában adva van az adott város lakóinak fejében. A mai budapesti, párizsi vagy dzsakartai közegben való eligazodás képessége nagyrészt abban áll, tudjuk-e, hol, mikor, milyen körülmények és szabályok közepette lesz módunk a magyar, francia vagy indonéz társadalom egyik vagy másik szeletével, informális körülmények között találkozni. Társadalmiságunk sikere nagyrészt az informális viszonyokban való eligazodás és részvétel sikerét jelenti.

A gazdaságszociológiában mára közhely, ${ }^{10}$ hogy az adott pillanatban alkalmazásban állók körében keresve sem találunk olyanokat, akik ne valamilyen informális kapcsolati elem révén tettek volna szert állásukra. Ezek közül általában a felületes, távolabbi ismeretségek a leghasznosabbak: nagyobb számuk és szélesebb társadalmi „merítési körük” jóvoltából e felületes ismeretségek több és értékesebb információt képesek gyüjteni és továbbítani az érdeklődőkhöz, és könnyebben hozzák tető alá az állásszerzés legfontosabb fázisát, az első kapcsolatteremtést a munkaadó és a munkakereső között, mint az intenzív összetartozást, szolidaritást és közösségélményt kifejező, sok esetben formalizált, nagyobb elkötelezettséget és befektetést igénylő, s emiatt jóval kisebb számban és szűkösebb skálán rendelkezésre álló,

10 Ez például Mark Granovetter, az új gazdaságszociológia egyik megalapítója első publikált monográfiájának (1974) alapmondanivalója. 
szorosabb kapcsolatok. ${ }^{11}$ Könnyü átérezni a „gyenge kötések ereje” képletben foglalt szociológiai tétel igazságtartalmát: bárki, aki ismeri például a tudományosság, a felsőoktatás, a müvészetek vagy a tágabb értelemben vett értelmiségi lét mindennapjait, pontosan tudja, milyen fontos része e területek szakmai életének az informális információátadás, segítségnyújtás és szolidaritás, illetve ezek ellentettje, az ugyancsak informális információeltitkolás, „fúrás” és „betartás”. Ugyanez mondható el a bürokráciák különböző szintjeiről, valamint a kis- és középvállalkozások egymáshoz füződő viszonyairól.

Az észak-amerikai kisvállalkozás-szociológia jó egy nemzedékkel ezelőtt mutatat meg elöször az etnikai hálózatok fontosságát: e szervezettípusban az azonos etnikai csoportba tartozó egyének mind „piaci”, mind nagyvállalati közegben, mind hierarchizált, mind pedig nagyszámú, hasonló rangú versenytárs jelenléte mellett igencsak ügyesen juttatják egymást a különféle vágyott társadalmi eröforrásokhoz azáltal, hogy etnikai csoportjuk többi tagjának informális úton rendelkezésére bocsátanak stratégiai pozícióikat. ${ }^{12}$ Így még a „fejlett” tőkés társadalmak legszabályozottabb, technológiailag legellenőrzöttebb, legfegyelmezettebb színhelyei - a hadsereg, a börtön és a munkahely - is az informális társadalmi viszonyok gazdag választékát kínálják. Mindez egyebek mellett arra is alkalmas volt, hogy kollektív tapasztalati alapjául szolgáljon a gazdaságszociológia Polányi Károly által jó két generációval ezelőtt megfogalmazott alaptételéhez a gazdasági cselekvés társadalmi beágyazottságáról (Polányi 1992 [1957]). ${ }^{13}$

\section{Az informalitás mint gazdasági szektor}

Az informalitás fogalmára ráépül egy másik szakterület is. Az összehasonlító fejlődés-gazdaságtan és a gazdaságszociológia határterületén kialakult nagy hatású irodalom, ${ }^{14}$ melynek tárgya az adófizetési, regisztrációs és szabályozással összefüggő előírásokat elkerülő, rejtőzködő vállalkozások és egyének gazdasági tevékenysége egy olyan közegben, ahol a hasonló tartalmú gazdasági tevékenységeket az adózás, a regisztráltság, a szabályozottság és a nyilvánosság ellenőrző hatalma jellemzi. ${ }^{15}$

Az e szektorba tartozó tevékenységek köre igen széles (erről lásd Portes, Castells és Benton 1989). Főbb típusaiként szokás megkülönböztetni:

11 E megfigyelés szolgál Granovetternél az „erős” és „gyenge kötések” közötti, fogalmilag meglehetősen pontatlan különbségtétel alapjául. Eredeti kifejtését lásd Granovetter (1973). A magyar társadalomra igen innovatív módon (kétdimenziós skálán) alkalmazta Angelusz és Tardos (1991).

12 Erről részletesebben lásd például Zhou (1992); Portes (1995); Light és Bonacich (1988); Portes, Castells és Benton (1989).

13 Általános gazdaságszociológiai tételkénti megfogalmazását lásd: Granovetter (1985).

14 Ennek alapműve Portes, Sassen és Koob (1987). Hasznosan összegzi a téma kiterjedt irodalmát Portes (1994); Portes és Schauffler (1993). Lásd még Waldinger és Lapp (1993).

15 E definícióból következik, hogy az e szektorban termelt és forgalmazott áruk és szolgáltatások tartalmának legalitása-illegalitása nem releváns. A formalitás-informalitás mint szektor distinkció szempontjából a törvényesség kizárólag mint az adózással, a nyilvántartással, a szabályozottsággal és a nyilvánosság betekintési jogával kapcsolatos törvények be nem tartása jön szóba. Fontos emlékezni arra, hogy az informális szektorban forgalmazott termékek és szolgáltatások túlnyomó része teljességgel legális mint termék/szolgáltatás. 
- a létfenntartás informális szektorát (lásd például Birkbeck 1979; Castells és Portes 1989), amely a létminimum szintjén kínál megélhetési lehetőséget Latin-Amerikában vagy Közép-Európában a nagyvárosok környékének szeméttelepein guberáló, a Rio de Janeiro-i, New York-i vagy kalkuttai utcákon tengődő, a mulatókban gyufát és cigarettát, a „jobb” Los Angeles-i útkereszteződésekben narancsot, a VIII. kerületben és a világ összes metropoliszának „vigalmi negyedeiben” elemi nemi szolgáltatásokat áruló nyomorultaknak,

- a centrumországok világvárosainak etnikai zárványaiban (például Zhou 1992), így a New York-i vagy Los Angeles-i kínai, vietnami, korábban olasz, lengyel, stb. negyedekben, müködő, sokban a tizenkilencedik századi Angliára emlékeztető nyomor körülményei között virágzó termelési tevékenységet és

- a hajlékony és alkalmazkodóképes gazdasági specializáció informális kisvállalkozói szektorát (lásd például Brusco 1982; Capecchi 1989) például az olaszországi Emilia Romagna tartományban vagy akár a hatvanas évek vége óta a magyar gazdaságban.

A világ szinte minden pontján fellelhető informális szektorban tevékenykedő legkülönfélébb osztály-, réteg- és kaszthelyzetű, minden rendű s rangú emberek életének, megélhetésének logikája azért társadalompolitikai kérdés, mert az informális szektor szociológiája implicit módon az államnak - a gazdaság működése feletti kollektív demokratikus ellenőrzés egyetlen potenciálisan hatékony közhatalmi intézményének - a szociológiája is.

A gazdasági tevékenységek regisztrálatlansága ugyanis láthatatlanná, s így védtelenné teszi a gazdaság szereplőit. Ez áll ugyan minden résztvevőre, de különösen igaz a gazdasági folyamatok alárendelt helyzetű szereplőire. Önmagában az, hogy a munkavállaló sikerrel ki tud bújni a munkajövedelmekhez kapcsolódó közteherviselési kötelezettség alól, csak kis részben kompenzálja a munkavégzés minden egyéb aspektusára kiterjedő teljes kiszolgáltatottságáért. ${ }^{16}$ A nyilvántartottság, illetve a termelési és kereskedelmi feltételek, körülmények szabályozottságának hiánya miatt ugyanez vonatkozik az informális szektor fogyasztóira is, különösképpen az informális közegben beszerzett, olcsóbb áruk minőségével kapcsolatban. A közintézmények ugyancsak megsínylik az informális szektor elharapódzását, hiszen a bevételek megcsappanása elszegényíti és a polgárral szemben egyre inkább ragadozói mentalitásra csábítja az államot, s eközben ellehetetleníti azon polgárait, akik a jóléti állam íratlan társadalmi szerződése alapján joggal vélik úgy, jogosultak arra, hogy részesüljenek az állam által biztosított köz- és magánjószágokból. Az elemzők politikai orientációjától és vérmérsékletétől függetlenül az informális szektor nemzetközi szakirodalmának egybehangzó megfigyelése, hogy ceteris paribus a gazdaság informalitása a tőkének kedvez mind a munkavállalóhoz, mind a fogyasztóhoz, mind pedig az államhoz füződő kapcsolatában.

Annak ellenére, hogy értelmezhető kapcsolatban nem állt az informalitás nemzetközi összehasonlító irodalmával, meglepően hasonló fogalmi rendszerben mozgott mind a magyarországi reform-közgazdaságtan, mind pedig az állampárt gazdasági reformpolitikai lépéseit megalapozó reformista intellektuális mozgalom. Az informalitás itt is a gazdaság egyik szektoraként jelent meg. Mindezt egy fogalmi csúsztatás tette lehetővé, ami hibásan kapcsolt össze két helyes tapasztalati megfigyelést. Ezen iskola képviselői helyesen mutattak

16 Hogy ez mivel jár, arról lásd - az informális munka magyar szakirodalmából - például Bodnár Judit (1999) és Sik Endre (1999a, 1999b) írásait. 
rá, hogy a magyar gazdaság nagy része a valóságban kívül esik a központi állami tervezés és ellenőrzés hatókörén. E szektor az államszocializmusra jellemző eufémizmussal a második gazdaság nevet kapta. Tovább kuszálta a dolgokat, hogy később a munkahelyi belső alvállalkozásra is a „második gazdaság” címkét kezdték alkalmazni. Ezt követték a KGST-piacok, a „kishatárforgalom” és a kis tételben zajló, „népi” csempészet, a prostitúció újraéledése, a regisztrálatlan szobakiadás és az utcai pénzváltás - s e nagyon is különböző jövedelemszerzési és költségcsökkentő intézmények is mind-mind a „második gazdaság” egyre dagadó fogalmába zsúfolódtak.

A reformerek arra is rámutattak, igen helyesen, hogy az ebben a nem tervezett és nem is állami tulajdonú szektorban a társadalmi viszonyokat pókhálószerüen át- meg átszövik a személyesség és az informalitás szálai. A kapcsolatrendszerek, amelyek a második gazdaságot alkotó egyéneket, illetve mikro- és kisvállalkozásokat egymáshoz füzték, megemelték az informális társadalmi hálózatrendszerek jelentőségét.

Mindkét megfigyelés empirikusan helyes volt. Ám csúsztatás volt olyatén egyszerű megfeleltetésük, mely szerint az első gazdaság formális, a második informális lett volna. Mindezt tetézte, hogy a reform-közgazdaságtan legjobbjai is hibásan olvasták a legjelentősebb magyar gazdaságantropológust, s a „piac kontra redisztribúció” kétosztatú sémájára egyszerüsítették Polányi híres mozaiktipológiáját - amely szerint bármely gazdasági rendszer az újraelosztás, a reciprocitás és a csere három alaptípusának sajátlagos, csak rá jellemző intézményekben megvalósuló együttállásával („mozaikszerü” összekapcsolódásában) határozható meg (lásd Kolosi 1986; Kolosi nyomán Böröcz 1989; Zentai 1999; Polányi 1992 [1957]). Mindez a következő fogalmi megfeleltetésekhez vezetett:

első gazdaság = állami vagy szövetkezeti tulajdon, redisztribúció és formalitás; második gazdaság = se-nem-állami-se-nem-szövetkezeti tulajdon, piac és informalitás.

E modell lényegében Gábor R. István és Galasi Péter egyik idevágó, fontos és eredeti meglátásának áramvonalasított változata volt. Ebben a szerzők az informalitást még az államszocialista gazdaság szektorális alapmegoszlásától viszonylag független kérdésként kezelték (Gábor és Galasi 1989: 21). A második gazdaság fogalmának hízásnak indulása, $s$ végül is a „sztálinista államszocialista modelltől való magyar eltérések” általános jelölöjévé válása során azonban egymásba fordult a két elemzési dimenzió, s a formalitás/informalitás megkülönböztetése mintegy rámásolódott az állami tulajdon/egyéb tulajdon megkülönböztetésre. A rendszerváltozást ezzel a meglehetősen leegyszerüsített fogalmi rendszerrel érte meg a magyar társadalom.

E kétosztatú modell - egyszerüsége és takarékos jellege folytán, illetve azért, mert pontosan illeszkedett a hidegháború hatalmi konstellációihoz, s így alkalmas volt arra, hogy mindkét oldalon, illetve mindkét oldal belső ellenzékénél politikai eszközzé váljék - igen népszerü fogalmi rendszer volt. ${ }^{17}$ Ugyanakkor a benne foglalt leegyszerüsítés miatt egyszerre jellemeze a rövid- és a csőlátás. Kizárólag a második gazdaságon belüli informalitásra irányította a figyelmet, s nem észlelte a „tervezett”, állami szektoron belül létező informalitást. Ezzel akadályozta, hogy felismerjük az államszocialista időszak vállalatvezetői körében ki-

17 Kornai például nagy eleganciával alkalmazza a szúkített Polányi-féle sémát a szektorális megoszlásra (lásd 1983, 1984, 1992a, 1992b). 
alakult, egyre komplexebb, többdimenziós informális társadalmi hálózatok gazdasági, politikai és kulturális jelentőségét. ${ }^{18}$

A reformszociológusok és -közgazdászok vonatkozó rövidlátását részben az is magyarázza, hogy az akkoriban népszerűvé vált fogalomnak, a „civiltársadalomnak” „az államtól viszonylag független, annak hatalmát korlátozó és ellenőrző társadalmi integrációs csoportosulások és tevékenységek" értelemben vett jelentése időközben az explicit, hangsúlyozott ellenzéki értelmiségi körökre szükült. Ennek különös következményei lettek. Hajlamosak lettünk megfeledkezni a csöndben, diszkréten az államszocializmus gazdasági, politikai és kulturális világából kivonult vagy attól eleve távolságot tartó maszekok, kisvállalkozók s minden rendü-rangú egyéb kisemberek millióiról és a félig a rendszeren belül, félig ennek repedéseiben megszólalásig nyugati kollégáikra emlékeztető vállalatvezetőkről mint a rendszerlazító civiltársadalom fogalmának lehetséges tagjairól. A civiltársadalomként megjelent ellenzék „kemény magja” egyébként (lásd például Javorniczky 1999) jó két-háromszáz emberre terjedt ki, s az ellenzékiség alapelemei - a házibulik, az aláírásgyüjtés, a bujkáló szellemi lét, a szamizdattevékenység, a nyugati sajtóval és egyetemi világgal való kapcsolattartás - mind-mind egy lényegét tekintve informális, kapcsolathálózati életforma habituális elemeit sulykolta résztvevőibe - $s$ negatív értelemben a társadalom azon tagjaiba is, akik ilyen vagy olyan, társaskapcsolati, földrajzi, korosztálybeli, habituális, stb. okoknál fogva kívül maradtak e körökön. A mai értelmiségi és politikai elitpozíciókért való - így az állami és magánpénzek, hatalom, megszólalási lehetőségek és presztízs elosztása körüli - iszapbirkózás mögött nagyrészt ugyanezek az informális társashálózati összefüggések - kapcsolódások és kizáródások - lelhetők fel.

Mindez nyitva hagyja azonban a kérdést, honnan származik az informális hálózatok mint magatartási minta történeti ereje.

\section{Az újra feltalált informalitás}

Közismert, hogy Kelet-Közép-Európa szerteágazó gazdaságtörténetének közös eleme a krónikus tőkehiány. A gyarmatosításból származó tőkefelhalmozási lehetőségekből földrajzi fekvésünknél illetve egyéb sajnálatos birodalmi környülállásoknál fogva kimaradtunk, a második jobbágyság és a korai kapitalizmus perifériás viszonyaira jellemző, folyamatos érték-kiszippantás következtében a kapitalizmus e tájon úgy-ahogy kialakulgató formái másodlagosak, rozogábbak és bizonytalanabbak voltak, s kezdettől fogva, alapszerkezeteikben függőségi viszonyban álltak a kapitalizmus néhány száz kilométerrel nyugatabbra, néhány száz évvel korábban, néhány száz százalékkal erőteljesebb struktúrákban létrejött válfajaitól. Mindezt már a századforduló táján pontosan látták régiónk legjobb társadalomtudósai. ${ }^{19}$

18 A tulajdonlás, a gazdasági integrációs mechanizmusok és a formalitás/informalitás dimenzióinak egy sorba állításának szarvashibáját kiküszöbölendő egyik volt aspiránsommal, Caleb Southworthszel együtt írott, magyarul is megjelent tanulmányomban (Böröcz és Southworth 1995) ezért bevezettem azt az egyszerű módosítást, melyben a formalitás-informalitás fogalmilag független az államszocialista gazdaság szektoraitól: mindkettő megjelenik mind az állami, mind a magánszektorban, mind pedig a kettő átfedését jelölő, gazdaságpolitikailag szürke zónában.

19 A megfigyelés, hogy Közép- és Kelet-Európa morfológiai jellegzetességei lényeges pontokon eltérnek az etalonként használt „Nyugat” ideáltipizált képzetétől, régtől fogva fontos motívuma volt régiónk modern szellemi életének. A vigyázó szemeit Párisra vető Batsányi nyomdokain e téma uralkodott a magyar szociológiát megteremtő Huszadik század körének gondolkodásában, s ez lengi át if. Leopold Lajos első világháború idején írott fontos társadalomtipológiai esszéjét (1988 [1914-17]). Romániában a Gîndirea folyóirat köre ugyanezekkel a kérdésekkel küszködik, nagyjából ugyanakkor (Schmitter 1978), s ez a Zeletin-Voinea-vita lényege is (Chirot 1978). 
Hogy valamely régiót épp az ipari kapitalizmus időszakában sújt a tőkehiány, az egyik fontos következménye, hogy a térség ipari üzemei a tőkével ellátottabb régiók hasonló vállalkozásainál kisebbek és kevésbé gépesítettek lesznek. Régiónk gazdaságtörténetét pontosan ez az alapvonás jellemzi a legiparosodottabb nyugat-európai vidékekkel való összehasonlításban. ${ }^{20}$ Mármost szokás szerint e különbséghalmazból általában a technológiai elmaradottság és az ebből levezetett alacsonyabb jövedelmezőség sorscsapásszerű fogalmára összpontosítunk. Én most másféle fókuszt javaslok. Gondoljuk végig azt, mik a kisebb méret és a kevésbé elörerohant gépesítettség társadalomformáló összefüggései a sorscsapás-mitológián és az önfelmentésen túl.

A méret és a gépesítettség mértéke szorosan összefügg a formalitás-informalitás mint társadalommorfológiai jellegzetesség kérdésével. Ha kiindulópontként elfogadjuk azt az állítást, hogy a társadalmi lét, benne az emberek megélhetését biztosító tevékenységek (röviden: a gazdaság) szervezeti viszonyainak nem a teljes formalizáltság, hanem a formalitás és az informalitás összjátéka a „természetes” müködésmódja, akkor a kisebb szervezetekre tagolt és viszonylag kevésbé gépesített iparosítás történeti tényéből két fontos következmény adódik. Elsőként az ipari szervezetek kicsiny méretéből és gépesítettségének korlátaiból a formális munkahelyi viszonyok viszonylagos gyengesége következik. A ma ismert erős, a társadalom pénzügyi erőforrásainak jó felét újracsatornázó, a társadalmi újratermelés minden szeletében jelenlevő államszervezethez fogható mértékben robusztus és formális belső szabályok bonyolult rendszerével összetartott ipari termelő szervezetek nélkül nem világos, vajon pontosan hol, milyen társadalmi helyzetben kellett volna-kellene a formalitásra vonatkozó fegyelmezési és morális normáknak kialakulniuk. A közép-európai állam hagyományos széttagoltsága, erőtlensége, legújabbkori történetének túlnyomó részét jellemző, tartós legitimációs válsága igencsak megrövidíti azon intézmények sorát, ahol a régió társadalmai modern történelmük utolsó száz-egynéhány éve során ki tudták volna kísérletezni, s meg tudták volna tanulni, miért s miként kellene alávetniük magukat a formalitás normaszerkezeteinek. A modern ipari kapitalizmus közép-európai története szinte kizárólag a kiskapukat nyitogató, informális mentalitást támasztja alá. Adott körülmények közepette - jobb híján írom le ezt a túlterhelt jelzőt - ez ugyanis az észszerü magatartás.

A közép-európai kapitalizmus e strukturális jellegzetességeinek megfelelően a magyar gazdaságtörténet a kisvállalkozások számszerü erejéről és ellenálló képességéről tanúskodik. A Nemzetközi Munkaügyi Szervezet 1930-as évektől folyamatosan rendelkezésre álló kiadványának tanúsága szerint például Magyarországon a kisvállalkozások, a magángazdálkodók és az „önállók” aránya rendre magasabb, illetve még a sztálinizmus időszakában is csak kicsivel alacsonyabb, mint Ausztriában vagy Németországban. ${ }^{21}$ A magyarországi önállók aránya csak a hetvenes évekre mutat csökkenést, ${ }^{22}$ vagyis e létforma túlélte az államszocialista átalakulást és sztálinizmust, s különösen a szolgáltatások területén jócskán belenyúlt a Kádár-

20 Mivel térségünk értelmező gazdaságtörténete Gerschenkrontól Wallersteinig, Bairochig és Berend-Ránkiig csaknem kizárólag erről szól, itt eltekintek attól, hogy megpróbáljam részletesen dokumentálni ezt az állítást.

21 A „munkaadók és függetlenek” aránya a jövedelemmel rendelkezők körében Magyarországon 1930-ban 21,1\% volt, s még 1960-ban is 12,9\%-on állt, a közbeeső államszocialista átalakulás és a sztálinista időszak minden magángazdaság-ellenes politikai terrorja ellenére. Ugyanebben az időszakban Ausztriában 9,4\%-ról 18,9\%-ra, Németországban pedig 16,4\%-ról 12,6\%-ra módosult a függetlenek és kisvállalkozók aránya. (Az 1960-as „németországi” adat az NSZK-ra vonatkozik.) (Lásd ILO 1930, 1960.)

22 1970-re a „munkaadók és függetlenek” aránya a jövedelemmel rendelkezők körében 2,4\%-ra csökkent Magyarországon (miközben Ausztriában 24,5\%-ra, az NSZK-ban pedig 9,1\%-ra módosult). (Forrás: ILO 1970.) 
korszakba. A magyar kisvállalkozói világ történeti-szervezettipológiai kontinuitását csak a második gazdaság tőkebefektetést egyáltalán nem igénylő területeinek felfutása szakította meg. Ezek legkézenfekvőbb módozata a háztájizás, illetve az állami és szövetkezeti tulajdonú termelöeszközök segítségével termelt javak és szolgáltatások informális úton történő, magáncélú elsajátítása volt. Ez egy lényegét tekintve igen szűk horizontú, korlátozott mozgásterü gazdasági stratégiát tett csak lehetővé.

E társadalom- és gazdaságtörténeti kontinuitás olyan vonásokat őrzött meg, melyek igen kevéssé kedveznek a nagyipari világban való eligazodáshoz, a sikerhez szükséges fegyelem, a személyesség nélküli bizalom és általában a formálisan szabályozott társadalmi viszonyok kialakulásának. A magyar társadalom gazdaság- és társadalomtörténeti csomagját nagyrészt ez, a kisemberi-kézművesvilág közvetlen kapcsolatokon, személyes etikán és egyedi viszonyokra kidolgozott bizalmon alapuló mentalitásbeli kontinuitása teszi ki. A kis ügyletek, kis profitok, kis vágyak, kis lehetőségek, kis távlatok világa nagyon sajátos, kistársadalmi világképben fejeződik ki. A magyar gazdaság- és társadalomtörténetből egy alapvetően kispályás s így értelemszerüen kiskapus szervezet-, mentalitás- és társadalmi viszonyulástípus uralma adódik.

E társadalom-alaktani megfontolás talán még arra is alkalmas lehet, hogy általa legalább e szempontból mentalitástörténeti kontextusába helyezzük a magyar történelem kádári korszakát. Az informalitás ugyanis olyannyira elterjedt és átható jellegzetessége volt az 1960-as évek Magyarországának, hogy a Kádár-rezsim sokat emlegetett, ellentmondásos engedményei csaknem kizárólag az informalitás világában valósultak meg.

A kádári politizálás lényege e vonatkozásban az aszimmetrikus jogi informalitás volt. A társadalom, a politika és a gazdaság életének csaknem minden területére behatoló, sztálinista korlátozásokat és elöírásokat csak nagy ritkán, akkor is félig-meddig és vonakodva törölték el. A hatvanas évek kádári innovációjának lényege a május elsejei kikacsintás volt: $a z a z$ expressis verbis soha, csak mimikában, beszéd-intonációban és egyéb metaszöveg-területeken artikulált informális ígéret, hogy a formális (sztálinista) szabályokat mi (=a hatalom) esetleg nem tart(at)juk be. Hogy pontosan mikor s mely szabályokat, törvényeket, elöírásokat tart(at) be a hatalom, s melyeket, s mily körülmények között nem, hogy mindez mitől függ, az ennek eldöntésére való képesség volt a politikai hatalom történeti-szociológiai definíciója a kádári államszocializmusban. Mivel a szabályok be (nem) tartására vonatkozó döntés definíció szerint informális, a kádári időszak hatalomgyakorlásába mélyen beépült az önkényes informalitás elvének e csendőrpertus változata. A lakosság szemében mindez a diktatúra egyfajta felpuhult, peróni-populista változataként tűnt fel; a moszkvai gazdához füződő viszonyban pedig a lehetőségekhez képest egy híres-hírhedt latin-amerikai minta - „engedelmeskedni, de nem végrehajtani” - mélyen közép-európai változatát valósította meg. A magyar társadalom pontosan „vette” az e kikacsintásban artikulált informális jelzést, s maga előtt sem tisztázta soha, gúnyból vagy visszakacsintásból janibácsizta kétes jellemű urát.

Itt lépnek be történetünkbe térségünk többi országának polgárai - méghozzá a szó szoros értelemben, s milliószámra. A hatvanas évek vége táján jelenik meg ugyanis Magyarországon a nemzetközi idegenforgalom, s indul meg az a társadalmi átalakulási folyamat, melynek már „csak” geopolitikai átállítástechnikai és rendszerváltás-levezényléstani részletkérdése volt az államszocializmus 1989-as hangtalan összeomlása. A magyar társadalom belső keletkezésű, történetileg öröklött informalitásának újbóli uralkodó mintává válását megkönnyítette s hatását megtöbbszörözte, hogy a kereskedelmi vendégfogadásra csaknem teljesen felkészületlen Magyarországon hirtelen milliós tömegben, elszántan kikapcsolódá- 
si célból megjelent az osztrák és a nyugatnémet társadalom jövedelmiosztály-piramisának alsó kétharmada, továbbá a keletnémet, lengyel és csehszlovák társadalom csaknem egésze. Az erre válaszul improvizált, informális megoldások témánk szempontjából két fő gazdasági következménnyel jártak: (1) az akkori időkhöz képest jelentős keményvaluta-bevételeket termeltek a jó időben, jó helyen „müködő” szobakiadóknál és egyéb idegenforgalmi mikrovállalkozóknál, s (2) az informális kelet-közép-európai kvázi-keményvaluta (erről lásd Böröcz 1992, 1996²3) rangjára emelték a forintot.

Mindez úgy is releváns a mai állapotok vonatkozásában, hogy az így keletkezett jövedelemtöbbletet csapolta meg ${ }^{24}$ az 1988-89-es évek bécsi magyar bevásárlóturizmusa, kiszippantván az országból a felhalmozott informális többletjövedelmek nagy részét. Ez jócskán hozzájárult ahhoz, hogy mire néhány éven belül sor kerül az állami vagyon privatizációjára, addigra a magyarországi lakosság kezében ne legyen számottevő tőkésíthető megtakarítás. Ugyanakkor az a jótékony hatása is megvolt, hogy jelentösen megemelte az oly kedélyesen a kiszolgáltatott helyzetú érintett kárára csúsztató, jellegzetesen bécsi hazugsággal a helyi újságokban „Magyar-hilferstraßéra” átkeresztelt bevásárlóutca kereskedőinek profitját, s így javította az osztrák kereskedelmi tőke jövedelmezőségét. (E töke egy része hamarosan formális-közvetlen külföldi befektetésként, illetve informális termőföld-felvásárlás keretében áramlott a magyar gazdaságba).

Amikor tehát 1999-ben az osztrák polgár a legális keleti munkaerő-beáramlás „rémétől” megriadva szélsőjobbra igazodik, egyebek mellett a megelőző húsz-huszonöt év közös, informális osztrák-magyar gazdaság- és társadalomtörténetét felejti el. Megfeledkezik az évente milliós számban igénybe vett apró szubvenciócskákról, melyeket a nevetségesen olcsó budapesti vendéglők, az aprópénzből kifizethető jegyárú operaelőadások, koncertek, balettelöadások, Puszta-show-k, a bécsi kombinált bérlet árából kigazdálkodott balatoni nyaralások, az osztrák munkanélküli-segélyből Magyarországon töltött nyarak, az olcsó pesti szex- és mulatókínálat nyújtott a ma Magyarország „EU-érettségét” összevont szemöldökkel megkérdőjelező, a „kelet-európai” elem ausztriai jelenlétét az érzékelhető bőrszín-árnyalatbeli különbségek hiánya ellenére rasszterminusokban ellenző osztrák polgár számára. Hogy ezt megteheti, annak legfőbb oka, hogy az elöző három évtized értékáramlása Magyarországról Ausztriába az informalitás szőnyeg alá söpörhető, Bécsben hanyag eleganciával a szőnyeg alá is söpört világában zajlott.

A kádári állam informális engedékenységét pontosan érzékelő magyar társadalom frenetikus állás- és egyéb jövedelemforrás-halmozásba fogott az államszocializmus utolsó tíz évében. Az idevágó adatok - melyek szerint a munkavállalók túlnyomó többsége részt vett a „második gazdaság” által kínált jövedelemszerző tevékenységek valamelyikében, legtömegesebben a háztáji kistermelésben - közismertek (lásd Kolosi 1984; KSH 1984: 7; ugyanakkor Sik 1995; Lackó 1996). Érvelésem szempontjából mindez annyiban érdekes, hogy a magyar

23 Utóbbiból lásd különösen a „The Splitting of International Leisure Migration in Hungary” és az „Informality and Tourism Receipts in Comparative Perspective" című fejezeteket.

24 Minden bizonnyal ez - a felhasználható, informálisan szerzett keményvaluta-megtakarítások megléte, illetve hiánya - magyarázza, hogy a bécsi kereskedők nagy csalódására a magyar bevásárlási lázat nem követte hasonló cseh és szlovák bevásárlási őrület. A csehszlovák államszocializmus összeomlását követően Bécsbe zarándokolt több milliónyi cseh és szlovák polgár intenzív érdeklődéssel, de a vásárlási készség minden jele nélkül járta be a Mariahilferstraße könnyű eladásra szakosodott, Gorenje hütőládákkal frissen feltöltött, cseh és szlovák nyelvü „Ne lopj!" feliratokkal frissen feldíszített üzleteit. 
társadalom az államszocialista gazdasági intézménytípusok - s ezek között kitüntetett helyen a központilag tervezett, államrezon által, racionális bürokráciák útján irányított, fordistamodern államszocialista nagyvállalat - által kínált szervezeti formákból való kihátrálása, s az államszocialista társadalmi formák kínálta magatartási mintáktól való, tömeges elfordulása során magától értetődő egyszerüséggel választotta ki társadalomtörténeti örökségéből az informalitás azon elemeit, melyek alkalmazhatónak tetszettek az 1980-as években. A magyar társadalom mai működésmódjának megértéséhez kulcsfontosságú adalék, hogy csaknem egész modern történetét az informális hálózatok kreatív felhasználásán alapuló, kisméretű, tőkehiányos, munka- és informáliskapcsolat-intenzív szervezetek elképesztően alkalmazkodásra képes mintája uralta. Hiába kísérleteztek a különféle rezsimek e habitus megváltoztatásával: amikor módja volt rá, a magyar társadalom nagy csoportjai csendben, de annál határozottabban újból alkalmazni kezdték ezt a társadalom-formatani alapképletet.

\section{Az informalitás mint erőforrás}

A nyolcvanas évek Magyarországán egyéb fontos társadalmi átalakulási folyamatok mellett lezajlott az informális társashálózati erőforrások eredeti felhalmozódása ${ }^{25}$ is. A hatvanas évek végén bevezetett reformok egyik társadalomszerkezeti következménye az volt, hogy megjelent a színen a nagy hatalmú gazdasági szereplők egy új típusa. Ez, elődeitől eltérően, már megszólalásig hasonlít a tőkés gazdaságban működő kollégáihoz, legalábbis a tekintetben, hogy sikerrel, esetenként kifejezett eleganciával és hatékonyan képes mozgósítani informális társas kapcsolatrendszerét akár vállalata, akár pedig saját maga érdekében. E vezetői hálózatok ugyanakkor gyakorlatilag teljességgel rejtve maradtak az akkor uralkodó reformdiskurzus szövegeiben. A mechanizmusreform és a piaci elemek akkori elemzési rendszerében ugyanis olybá tünt, mintha az időszak átalakulása csupán abban állna, hogy egy korábban erőteljesen centralizált gazdaságirányítási rendszert egy kevésbé központosított rendszer vált föl. Ezt az új rendszert volt hivatva megragadni a „tervalku” megindítóan pontatlan fogalma. Ebbe az állítólag tervezett (értsd: „korlátozott”) rendszerből az úgymond „piaci” (értsd: „szabad”) rendszer felé való elmozdulást jelezni hivatott fogalomba „csak” az a hallatlanul gazdag, szellemes, sokszor önellentmondásos, szívességeken, összetartozás- és kizárástudaton alapuló, presztízsben és soha, semmilyen formában nem rögzített, apróbbnagyobb privilégiumokban és újraelosztási-sormegkerülési lehetőségekben jutalmazott, rokon- és ellenszenvre, baráti és ellenséges taktikázásra, lobbizásra, klikk- és koalícióalakí-

25 Van, aki Bourdieu és Coleman nyomán minderre a „társadalmi tőke” fogalmát használja. (Az ide vágó szakirodalom hasznos összefoglalását kínálja például Portes 1998). Én a „társashálózati erőforrások” fogalmát alkalmazom, vagyis elkerülöm a társadalmi tőke fogalmát e vonatkozásban, mégpedig azért, mert pongyolaságnak találom a tőke mint metafora használatát a szigorú értelemben gazdasági folyamatokon kívül, így az informális kapcsolatok vonatkozásában is. Véleményem szerint a tőke fogalmának gazdaságon kívüli jelenségekre való alkalmazása (kulturális tőke, politikai tőke, társadalmi tőke stb.) elfed egy sor, a szociológiai elemzés számára rendkívül fontos különbséget például az értékesülés intézményrendszere és az értékkonverzió, a befektetés megtérülésére vonatkozó reális várakozások, valamint a nem gazdasági „tőkeformák” önértéke vonatkozásában. Más szóval a tőke mint metafora mintegy úgy állítja be a társadalom kulturális, politikai és társashálózati mezőjét, mint aminek müködése nagyjából hasonlít a gazdasági tőkééhez - ez pedig olyan egyszerüsítés, amit nem akaródzik bevezetnem. Ugyanakkor a társadalmi tőke fogalmának metaelméleti kritikája bőven megérdemelne egy egész tanulmányt, amire e keretben nincs módom. Tehát mintegy teszek egy lépést hátrafelé, s az erőforrások kevésbé specifikus nyelvezetét használom. 
tásra, csoport-együttmüködésre, -lojalitásra, a közvetlen és közvetett kényszerek, zsarolás és viszontzsarolás millió apró trükkjére alapozott, mozgékony és fölöttébb alkalmazkodóképes gazdasági integrációs forma „nem fért bele”, amelyben a nyolcvanas évek vállalati vezetői, állami hivatalnokai, szabályozó-kidolgozó és döntéselőkészítő szakértői aktívan részt vettek. Kis túlzással azt mondhatnánk, a „tervalku” fogalma által megragadni kívánt világban szinte minden megvolt - talán csak a tervezés és az alkudozás szociológiai cselekményei nem.

A hatvanas évek végén megindult magyarországi átalakulási folyamatok a „tervalkunál” gazdagabb, egyszerre szociológiaibb, antropológiaibb és történetibb megragadást érdemeltek volna. Szerencsés lett volna például rögzíteni, hogy a gazdaság állami tulajdonú, nagyobbik hányadában olyan átalakulás zajlott le, ami fogalmilag nagyban hasonlít a centrumországokban az előző századforduló táján történt váltásra, amennyiben lényege az átállás a tulajdonos által vezetettböl a menedzserek által irányított vállalati szervezetre. Hasonlóan ahhoz, ahogy a legnagyobb amerikai családi vállalkozások átadták helyüket a részvényesek tulajdonolta, menedzseri irányítású vállalati rendszernek, a magyar gazdaságban is ugrásszerüen megnövekedett a vezetők hatalma a tulajdonosokéhoz képest. $\mathrm{Az}$ államszocialista gazdaságban a túlsúlyos többségi tulajdonost, az államot ennek Max Weber-i értelemben racionális bürokráciái, konkrétan a tervező, végrehajtó és ellenőrző apparátusok képviselték. Ezen apparátusok hatalmát korlátozták a hatvanas évek második felétől, a gazdasági élet élénkítése céljából bevezetett reformok. Az állam, amely államszocialista változatában egyszerre képviselt tulajdonosi, regulátori, ellátási és jóléti funkcióinak következtében súlyos, többoldalú szerepkonfliktusban szenvedett, szerepzavarát tulajdonosi feladatainak fokozatos, részleges és féloldalas, sokszor önellentmondásos elhanyagolásával és elfojtásával „kezelte”, majd csendben, végleges lecserélése előtt még átpasszolta a labdát a vállalatvezetőknek. Ennek következtében a magyar gazdaság a szó szociológiai értelmében államszocializmusból egyfajta különös menedzseri szocializmussá vedlett át. E rendszernek a vezetők informális társashálózati erőforrásai, s ezeknek az állami erőforrásokhoz kapcsolódó értékesülési lehetőségei biztosítottak koherenciát.

Mindez messze vezet. Az informalitás kérdéséhez csupán annyiban kapcsolódik, hogy az új vezetői szabadságélményben magától értetődő természetességgel fonódott össze az informalitás és a vállalatvezetői siker. Az informális hálózatok kezelése és célirányos felhasználása a vállalatvezetői lét egyik kulcseleme lett.

\section{Az informális kapcsolatok értékesülése}

Az 1989-ben kialakult magyar politikai spektrum tagjai kis túlzással egyetlen dologban értettek egyet: abban, hogy gyökeresen vissza kell venni az állam részvételét gazdaságban. A nyilvános beszédben, a közéletben, az újságokban és a szakértők gondolkodásmódjában e nem túl bonyolult közös platform a neoklasszikus közgazdaságtantól kölcsönzött nyelvezetben jelent meg. Ez azért volt lehetséges, mert a neoklasszikus közgazdaságtan a társadalomtudományoknak talán az egyetlen olyan ága, amely teljes komolysággal képes arra, hogy az államot kizárólag mennyiségi fogalomként képzelje el. Így volt lehetséges, hogy a politikai vitákat a „több” kontra „kevesebb állam” nem túl cizellált fogalmi rendszere, s a „kevesebb állam” fogalmának a „közjóval” való azonosítása tartsa hatalmában. Az állami hatalom legfelső régióiban ez a gondolat (1) az állami tulajdonlás mint intézményi forma 
megszüntetésére, (2) az állam szabályozó, a munkavállalót, a társadalmi reprodukciót és a környezetet védelmező szerepének korlátozására, illetve (3) jóléti funkcióinak átszervezésére és elsorvasztására irányuló politizálásban öltött testet.

Nem jelentett leküzdhetetlen akadályt a tőkésítésíthető megtakarítások csaknem teljes hiánya sem. A tulajdonváltás óhaja és a felhasználható belföldi anyagi erőforrások hiánya közötti feszültségből keletkező tulajdonvákuumot tovább növelte a privatizáció technikai problémáinak tömege. Az összes rendszerváltó párt „privatizációt bármi áron” követelő programjai abban is összhangot mutattak, hogy kimaradt belölük az informalitás képzete. A magyar gazdaság teljes jövedelemtermelésre alkalmas tulajdonállományának privatizációját minden szóba jövő párt, s ezek jószerével minden közgazdász, jogász és szociológus szakértője úgy képzelte el, mintha az informalitás, a magyar társadalom e szerveződésmódja egyáltalán nem létezne.

A tulajdonvákuum két erőforrástípust szippantott magába. Ezek egyike a külföldi tőke volt. A volt szovjet blokk Szovjetunión kívüli részének durván 10\%-át kitevő Magyarországon jelent meg a térségbe áramlott közvetlen tőkebefektetések jó fele-harmada. A másik tulajdonátalakítási erőforrástípus a gazdaság közgazdaságtani fogalmán kívülről érkezett: ennek a szaktudás és a gyakorlati ismeretek mellett igen nagy részét az informális társashálózati erőforrások tették ki. A gazdaság tulajdonlási és irányítási rendszerében történt rendszerváltás fő belföldi elemét az előző időszak során felhalmozott informális hálózati erőforrások értékesülése jellemezte.

Emiatt az idevágó, jó hangosan elharsogott neoklasszikus várakozásokkal ellentétben a „piacgazdaságra” és a kapitalizmusba való átmenet nem söpörte el a magyar gazdaság „elmaradott”, informális jellegzetességeit. Különösen a tulajdonváltás legelső időszakában nem, amikor a pozícióban levő vezetők irigylésre méltó élelmességgel váltották át informális hálózatokban „fekvő” erőforrásaikat az új, kapitalizmuskonform vállalatok vezetői és - esetenként némi késéssel, de egy lendülettel - tulajdonosi pozícióira is. ${ }^{26}$

A közvetlen külföldi tőke megjelenése egyébként ugyancsak az informalitás, különösen az informális vezetői kapcsolatrendszerek hegemóniáját erősítette. Mivel a pontos vállalatgazdálkodási információk, a munkavállalói együttmúködési hajlam, a könyvelési precizitás, a pénzáramlás, a készletgazdálkodás, a piacrészesedés és a technológiai fegyelem mind-mind fontos eleme a sikeres tulajdonátalakulásnak, az „öröklött” vezetők kapitalizmuskonform része fontos szolgálatot tett az új tulajdonosoknak. Mivel a legjobb magyar vállalatok ekkorra már mind jelen voltak a világpiacon, a jelenléttel járó informális ismeretségek tovább könnyítették a tulajdonátadás-átvétel folyamatát. Európa legeladósodottabb államának árverőügynöksége nyolc évig a privatizáció „történelmi nehézségeit” hajtogatta a tudálékosan bólogató politikai elitnek. Így volt lehetséges, hogy noha a magyar állami vagyon magánosítása jó esetben nullszaldósra sikerült, ebből nem országra-világra szóló botrány

26 Emlékeztetőül, az 1999. szeptemberi korrupciós hírek rovatból: vezérigazgatója tárgyalja az állami tulajdonú bank eladását külföldi befektetőkkel. Az ügylet része, hogy az átírást követő napon az eddigi vezér az igazgatótanács elnöke lesz, s egyben opciót kap arra, hogy három millió dollár értékben vásárolhasson a bank részvényeiböl. Ennek megkönnyítése végett kamatmentes, rövid távú hitelt vehet fel a banktól éppen hárommillió dollár értékben. Elegendő a rövid távú hitel, ugyanis a bank két nap múlva visszavásárolja tőle a részvényeket 270\%-os árfolyamon. A keletkező, ötmillió dolláros nyereség - adott pillanatban a magyarországi éves átlagjövedelem ezerszerese - mint üzleti jövedelem, adómentes. Az elnök egyetlen megjegyzést füz az ügylethez: nem érti, mitől volna érdekes ez a teljesen konvencionális privatizációs ügylet a nagy nyilvánosság számára. 
kerekedett, hanem miniszterelnöki öngratuláció a sikeres privatizáció befejezése miatt. ${ }^{27}$ Józan ésszel aligha lehet kizárni, hogy az állami tulajdon ilyen mértékben a végső tulajdonos - a társadalom - érdeke szempontjából hátrányos, a vásárló számára ennyire elönyös eltulajdonítása korrupciómentes körülmények között zajlott volna. A tőkejavak e világtörténetileg példátlan arányú magánkézbe juttatása az informalitás ethoszának uralmával valósult meg. A magyarországi gazdasági átalakulás képletszerüen így összegezhető tehát: államilag levezényelt adósság-tulajdon-csere (angol szaknyelvi kifejezéssel: 'debt-equity swap'), jórészt informális társadalmi mechanizmusok révén.

Ami a gazdaság többi részét illeti, a magas infláció körülményei és a bankrendszer sajátosságai következményeképpen eközben a bennszülött üzletemberi osztály kialakulása számottevő akadályokba ütközött. A belföldiek által milliószámra létrehozott, kicsiként indult új vállalkozások egy része megszünt, másik része vegetál, harmadik része a közterhek elkerülésére alapított kényszervállalkozás. A maradék úgy-ahogy müködik, de - s érvelésem szempontjából ez a legfontosabb - a még létező, tényleges üzleti tevékenységet folytató vállalatok túlnyomó része kicsiny maradt. A sok kisvállalkozás szervezeti értelemben vett növekedésének strukturális korlátai csak tovább erősítették az informalitás magatartás- és attitüdbeli pozícióit. Saját vállalkozásuk növekedésének elmaradása aligha fel nem tűnt a tényleges vállalkozóknak. Az elmúlt nyolc-tíz év tapasztalatai tehát arra tanították meg nagy többségüket, hogy vállalkozói jövőjüket bizony valószínüleg továbbra is a kicsiny méret okozta jelentéktelenség, a kiszolgáltatottság, a gazdasági környezetük átfogó összefüggéseit befolyásolni képtelenség fogja jellemezni. A hazai vállalkozók többsége megtanulta, tudja, „hol a helye”. Magatartását, stratégiáját eszerint alakítja.

A jogi környezet ugyancsak hozzájárult az informalitás uralmához. A személyi jövedelemadózás magyarországi rendszere például, mint a nyájas olvasó minden bizonnyal saját bőrén tapasztalja, igen erőteljesen ösztönzi a vállalkozásalapítást - az olyan gazdálkodási tevékenységek (pl. a munkavállalás) és gazdálkodási egységek (pl. a nukleáris család) esetében is, amelyek távolról sem merítik ki a vállalkozás gazdaságszociológiai fogalmát. A vállalkozásalapítási kényszerek, amelyeket egyébként az egymást követő kormányok egymással versengően doktriner monetarista világképe hozott létre, az informalitás felé tolták el a magyar társadalmat, hiszen abszurd módon és mértékben kitágították a bejegyzett üzleti vállalkozás fogalmát. Amikor egy négytagú család betéti társulásként jelenik meg az adóhivatali nyilvántartásban, $s$ forgalmiadó-mentességet vesz igénybe a családi autóval, vasárnap, a nagymamához tett falusi kirándulás költségeire, a gyerekek új tornacipőjére vagy a heti bevásárlásra, vagy amikor még a bölcsészkari tanszékeknek sem maradnak alkalmazottai, mert az oktatók és az adminisztrátorok egyaránt bétés alvállalkozóként veszik fel a jövedelmüket, az üzleti vállalkozás bejegyzése egyre inkább ügyes adóelkerülési trükkre kezd emlékeztetni. A számlaadás megtagadása ma annyira elterjedt Magyarországon, hogy a szolgáltatások jelentős részében felállt a kettős árrendszer (számlával/számla nélkül). Mindez alaposan hozzájárul a törvények, különösen a gazdasági törvények komolyságának megkérdőjelezéséhez, s jórészt azt is megmagyarázza, hogyan lehetséges, hogy - mint Kim Lane Scheppele és Örkény Antal (1996-1997) oly pontosan rögzíti - Magyarországon az alkotmányosság szintjén

27 Gondolatkísérletként képzeljük el, bármely német, francia vagy amerikai nagyvállalat vezetője megtehetné-e, hogy a vállalat tulajdonportfóliójának több mint 90\%-át eladva „sikeres tulajdoneladásról” számoljon be egy olyan mérlegbeszámoló után, amelyben az elárusítás tranzakciós költségei nagyjából felemésztik a teljes árbevételt. 
szigorúan és pontosan érvényesülő törvényesség azon nyomban elillan, amint az állampolgár és az állam viszonyáról van szó, miközben az állampolgárok egymás közti viszonyait az informalitás személyre szabottsága és önkényessége szabályozza.

Mindennek láttán nehéz más következtetésre jutni, mint hogy az informalitás kulcsszerepet játszott-játszik a magyar gazdaság átalakulásában. A tulajdon-átalakulás során végbement tranzakciók csak nagy távolból emlékeztetnek a formális közgazdaságtan által tételezett folyamatra, melyben egymással versengő, saját érdekeiket állhatatosan képviselő eladók és vevők kara kizárólag árak útján való kommunikációban kialakított, világpiaci árviszonyokat tükröző, egyensúlyi árakon cseréli ki az ügylet tárgyait a kölcsönös előnyök és a gazdasági hatékonyság jegyében. Talán fogalmi és történelmi élménykör tekintetében távolból, félig behunyt szemmel, erős ködben, a nyelvet és a közeget nem ismerő, a neoklasszikus modell tagadhatatlan esztétikai értékeinek hatása alatt álló megfigyelőknek így tűnhet. Kicsit közelebbről nézve, újmagyarul megfogalmazva már kiderül: informális kapcsolatrendszerek és eljárásmódok által szervezett lenyúlás, szűk játékterü, kispályás nyomulás folyik.

\section{Összefoglalva:}

I. két fő különbség figyelhető meg a poszt-államszocialista Magyarország és „a nyugati minta" között:

1. mint az ország modern történelmében mindig, a társadalmi lét nagyobb területére terjed ki az informalitás; ugyanakkor

2. a formalitás életvezetési mintaként kevésbé járja át a társadalmat, mint a „nyugati” önreflexióban.

II. E különbségek az ország társadalom- és gazdaságtörténeti örökségével függnek össze, ezen belül:

- $\quad$ a modern szervezetek, különösen az üzleti vállalkozások kisebb méretével és széttöredezettebb szerkezetével;

- a kisiparosi-kisvállalkozói-kisparaszti-kisemberi világ ellenálló képességével és az ezzel összefüggő mentalitásbeli örökséggel;

- a társadalom nagy részének a szocialista állam modernista társadalomátalakító projektjeivel - különösen a szocialista nagyüzem kulturális mintateremtő kísérleteivel - szembeni ellenálló képességével;

- a második gazdaság informális kapcsolatrendszer-teremtő és -jutalmazó hatásával;

- a nyolcvanas évek menedzseri szocializmusával, amely módot adott az informális menedzseri kapcsolati erőforrások eredeti felhalmozódására; s végezetül

- a (fél)perifériás lét belső tőkehiányával, amely megteremtette az informális eljárások sikerének mind a feltételeit, mind pedig az ösztönzőrendszerét.

Mindezzel kapcsolatban, úgy tűnik, négy értelmesen megvitatható kérdés merül fel.

a) Összhangban van-e a fenti leírás a tapasztalati tényekkel?

b) Ha igen, csapás-e az informalitás ilyetén kiemelt szerepe?

c) Lehet-e, szabad-e, kell-e valamit tenni e tárgyban?

d) Ha lehet, szabad, netán kell, akkor kinek és mit lehetne /szabadna/ kellene tennie? 


\section{Hivatkozott irodalom}

Angelusz Róbert és Tardos Róbert (1991): Hálózatok, stílusok, struktúrák. Budapest: ELTE Szociológiai Intézet.

Birkbeck, Christopher (1979): Garbage, Industry and the 'Vultures' of Calí, Colombia. In Casual Work and Poverty in Third World Cities. Ray Bromley és Chris Gerry (szerk.). New York: John Wiley, 161-136.

Bodnár Judit (1999): Moszkva téri mozaik: Társadalmi átalakulás a nyilvános térben és a piac délibábja. 2000 (december): 50-62.

Bodnár, Judit és József Böröcz (1998): Housing Advantages for the Better-Connected Institutional Segmentation, Settlement Type and Network Effects in Late State-Socialist Housing Inequalities. Social Forces 76(4): 1275-1304. DOI: https://doi.org/10.2307/3005835

Böröcz József (1989): Mapping the Class Structures of State Socialism in East-Central Europe. Research in Social Stratification and Mobility (8): 279-309.

Böröcz József (1990): A kádárizmustól a parlagi kapitalizmusig: a fejlett informalizmus építésének időszerü kérdései. Mozgó Világ (8): 61-67.

Böröcz József (1992): Dual Dependency and the Informalization of External Linkages: The Case of Hungary. Research in Social Movements, Conflicts and Change (14): 189-209. [Magyarul: 1993: "Kettős függőség és a külső kötések informálissá válása." Eszmélet (18-19): 74-88.]

Böröcz József (1993): Simulating the Great Transformation: Property Change under Prolonged Informality in Hungary. Archives européennes de sociologie / Europäisches Archiv für Soziologie / European Journal of Sociology 34(1): 81-107. DOI: https://doi.org/10.1017/s0003975600006561 [Magyarul: „Színlelt nagy átalakulás? Informális kiút az államszocializmusból." (Farkas Katalin fordítása alapján.) Politikatudományi Szemle. 1995, 3 (ősz): 19-39.]

Böröcz József (1996): Leisure Migration: A Sociological Study on Tourism. Oxford: Pergamon Press.

Böröcz, József és Ákos Róna-Tas (1995): Small Leap Forward: Emergence of New Economic Elites. Theory \& Society 24(5): 751-781. DOI: https://doi.org/10.1007/bf00993405

Böröcz József és Caleb Southworth (1995): Kapcsolatok és jövedelem: Magyarország, 1986-87. Szociológiai Szemle 5(2): 25-48.

Böröcz József és Caleb Southworth (1996): Decomposing the Intellectuals' Class Power: Conversion of Cultural Capital to Income, Hungary, 1986. Social Forces 74(3): 797-821. DOI: https://doi.org/10.2307/2580382

Brusco, Sebastiano (1982): The Emilian Model: Productive Decentralization and Social Integration. Cambridge Journal of Economics 6(2): 167-184. DOI: https://doi.org/10.1093/oxfordjournals.cje.a035506

Capecchi, Vittorio (1989): The Informal Economy and the Development of Flexible Specialization. In The Informal Economy: Studies in Advanced and Less Developed Countries. Alejandro Portes, Manuel Castells és Lauren Benton (szerk.). Baltimore: The Johns Hopkins University Press, 189-215.

Castells, Manuel és Alejandro Portes (1989): World Underneath: The Origins, Dynamics and Effects of the Informal Economy. In The Informal Economy: Studies in Advanced and Less Developed Countries. Alejandro Portes, Manuel Castells és Lauren Benton (szerk.). Baltimore: The Johns Hopkins University Press, 11-37.

Chirot, Daniel (1978): Neoliberal and Social Democratic Theories of Development: The Zeletin-Voinea Debate Concerning Romania's Prospects in the 1920's and Its Contemporary Importance. In Social Change in Romania, 1860-1940. A Debate on Development in a European Nation. Kenneth Jowitt (szerk.). Berkeley: Institute of International Studies, University of California, 31-52.

Gábor R. István és Galasi Péter (1981): A „második” gazdaság. Tények és hipotézisek. Budapest: Közgazdasági és Jogi Könyvkiadó.

Granovetter, Mark (1973): The Strength of Weak Ties. American Journal of Sociology 78(6): 1360-1380. DOI: https://doi.org/10.1086/225469 [Magyarul: A gyenge kötések ereje. A hálózatelmélet felülvizsgálata. (Ford. Molnár Attila.) In Társadalmak rejtett hálózata. Angelusz Róbert és Tardos Róbert (szerk.). Budapest: Mühely (MKI). 1991, 371-400.]

Granovetter, Mark (1974): Getting a Job. A Study of Contacts and Carreers. Cambridge: Harvard University Press.

Granovetter, Mark (1985): Economic Action and Social Structure: the Problem of Embeddedness. American Journal of Sociology 91(3): 481-510. [Magyarul: A gazdasági intézmények társadalmi megformálása: a beágyazottság problémája. (Ford. Kemény Szabolcs.) In A gazdasági élet szociológiája. Lengyel György és Szántó Zoltán (szerk.). Budapest: Aula. 1996, 61-78.]

ILO (1930, 1960, 1970): Yearbook of Labour Statistics (kiválasztott évfolyamok). Geneva: International Labour Office.

ILO (1995): Social Expenditure in Central and Eastern Europe Under Challenge: Financing a Decent Society or Cutting Corners? Geneva: International Labor Office. 
Ipargazdasági Intézet (1993): The Informal Sector in Hungary. Report Prepared with Support from the Center for International Private Enterprise as Part of the Project, „Legal and Regulatory Reform”. Interneten: http: //www. cipe.org/efn/fme2.html.

Javorniczky István (1999): Charta '79. Élet és Irodalom, 48. Interneten: http://es.fullnet.hu/9948/publi.htm.

Kolosi Tamás (1984): Státusz és réteg. Rétegződésmodell-vizsgálat III. Budapest: Társadalomtudományi Intézet.

Kolosi Tamás (1986): Strukturális csoportok és a reform. Valóság (7): 19-32.

Kornai János (1983): Bürokratikus és piaci koordináció. Közgazdasági szemle (30)9: 1025-1038. [Angolul: Bureaucratic and Market Coordination. Osteuropa Wirtschaft 1984, 29(4): 306-19.]

Kornai János (1984): Bürokratikus és ipari koordináció. (Akadémiai székfoglaló 1983. április 16.) Budapest: Akadémiai.

Kornai János (1992a): The Socialist System. The Political Economy of Communism. Princeton, NJ: Princeton University Press.

Kornai János (1992b): The Affinity Between Ownership and Coordination Mechanisms. The Common Experience of Reform in Socialist Countries. In Constructing Capitalism. The Reemergence of Civil Society and Liberal Economy in the Post-Communist World. Kazimierz Poznanski (szerk.). Boulder: Westview, 97-116.

KSH (1984): Idöfelhasználás a mezőgazdasági kistermelésben I. Budapest: KSH.

Lackó Mária (1995): Rejtett gazdaság nemzetközi összehasonlításban. Becslési módszer a háztartási villamosenergia-fogyasztás alapján. Közgazdasági Szemle 52(5): 486-510.

Leopold Lajos, ifj. (1988 [1914-17]): Színlelt kapitalizmus. Medvetánc (2-3): 321-55.

Light, Ivan és Edna Bonacich (1988): Ethnic Entrepreneurs: Koreans in Los Angeles, 1965-1982. Berkeley: University of California Press.

Örkény Antal (1997): Hétköznapok igazsága. Igazságossági felfogások egy nemzetközi összehasonlítás tükrében. Budapest: Új Mandátum.

Polányi, Karl (1992 [1957]): The Economy as Instituted Process. In The Sociology of Economic Life. Swedberg, Richard és Mark Granovetter (szerk.). Westview Press, Boulder, 29-51. [Magyarul: A gazdaság mint intézményesített folyamat. (Ford. Kis János.) In A gazdasági élet szociológiája. Lengyel György és Szántó Zoltán (szerk.). 1996. Budapest: Aula, 37-48.]

Portes, Alejandro (1994): The Informal Economy and Its Paradoxes. In The Handbook of Economic Sociology. Neil J. Smelser és Richard Swedberg (szerk.). Princeton: Princeton University Press, 426-450.

Portes, Alejandro (1995): The Economic Sociology ofImmigration: Essays on Networks, Ethnicity, and Entrepreneurship. New York: Russell Sage Foundation.

Portes, Alejandro (1998): Social Capital: Its Origins and Applications in Modern Sociology. Annual Reviews of Sociology (24): 1-24. DOI: https://doi.org/10.1146/annurev.soc.24.1.1

Portes, Alejandro, Manuel Castells és Lauren A. Benton (1989): The Informal Economy: Studies in Advanced and Less Developed Countries. Baltimore: The Johns Hopkins University Press.

Portes, Alejandro és Saskia Sassen-Koob (1987): Making It Underground: Comparative Material on the Informal Sector in Western Market Economies. American Journal of Sociology 93(1): 30-61. DOI: https://doi. org/10.1086/228705

Portes, Alejandro és Richard Schauffler (1993): Competing Perspectives on the Latin American Informal Sector. Population and Development Review 19(1): 33-60. DOI: https://doi.org/10.2307/2938384

Scheppele, Kim Lane és Antal Örkény (1996-1997): Rules of Law. The Complexity of Legality in Hungary. International Journal of Sociology 26(4): 76-94. DOI: https://doi.org/10.1080/15579336.1996.11770149

Schmitter, Philippe (1978): Reflections on Mihail Manoilescu and the National Consequences of Delayed Dependent Development on the Periphery of Western Europe. In Social Change in Romania, 1860-1940. A Debate on Development in a European Nation. Kenneth Jowitt (szerk.). Berkeley: Institute of International Studies, University of California, 117-173.

Sik Endre (1996): Egy ló-öszvér a lovakról és a szamarakról. Adalék a második gazdaság hazai eszmetörténetéhez. Közgazdasági Szemle 18(7-8): 704-25.

Sik Endre (1999a): Emberpiac a Moszkva-téren. In Átmenetek. Az MTA Politikai Tudományok Intézete Nemzetközi Migráció Kutatócsoport Évkönyve, 1999. Sik Endre és Tóth Judit (szerk.). Budapest: MTA PTI, 81-108.

Sik Endre (1999b): Magyarok az osztrák munkaerőpiacon. In Átmenetek. Az MTA Politikai Tudományok Intézete Nemzetközi Migráció Kutatócsoport Évkönyve, 1999. Sik Endre és Tóth Judit (szerk.). Budapest: MTA PTI, 123-72.

Stark, David (1996): Recombinant Property in East European Capitalism. American Journal of Sociology 101(4): 991-1027. DOI: https://doi.org/10.1086/230786 
Stark, David és László Bruszt (1998): Restructuring Networks in East European Capitalism. In Postsocialist Pathways: Transforming Politics and Property in East Central Europe. David Stark és László Bruszt (szerk.). Cambridge, UK: Cambridge University Press, 137-165.

Tamás Gáspár Miklós (1997): A magyar liberalizmus válsága. I. rész. Magyar Narancs (május 29.): 36-39.

TÁRKI (1988a): A TÁRKI III. Felvétel Dokumentumai. II. kötet. Budapest: Társadalomkutatási Informatikai Társulás.

TÁRKI (1988b): TÁRKI-I. Terjeszti a Társadalomkutatási Informatikai Társulás. Budapest: TÁRKI.

TÁRKI (1988c): TÁRKI-III. Terjeszti a Társadalomkutatási Informatikai Társulás. Budapest: TÁRKI.

Waldinger, Roger és Michael Lapp (1993): Back to the Sweatshop or Ahead to the Informal Sector. International Journal of Urban and Regional Research 17(1): 6-29. DOI: https://doi.org/10.1111/j.1468-2427.1993.tb00209.x

Williamson, Oliver (1981): The Economics of Organization: The Transaction Cost Approach. American Journal of Sociology (87): 548-577. DOI: https://doi.org/10.1086/227496

Williamson, Oliver (1994): Transaction Cost Economics and Organization Theory. In The Handbook of Economic Sociology. Neil J. Smelser és Richard Swedberg (szerk.). Princeton: Princeton University Press, 77-107.

Zentai Violetta (1999): Győztesekből tettesek, vesztesekből áldozatok? Kétosztatú társadalomképek a rendszerváltás magyarországi kritikájában. 2000 (szeptember): 10-20.

Zhou, Min (1992): Chinatown: The Socioeconomic Potential of an Urban Enclave. Philadelphia: Temple University Press.

\section{Böröcz József}

Egyetemi tanár, Szociológia Tanszék, Rutgers Egyetem; kutatóprofesszor, Társadalmi Kommunikáció Doktori Iskola, Budapesti Corvinus Egyetem 
